\title{
DEVELOPING ENGLISH READING MATERIALS FOR THE ELEVENTH GRADE STUDENTS OF MARITIME DEPARTMENT OF SMK PELAYARAN SAMUDERA INDONESIA
}

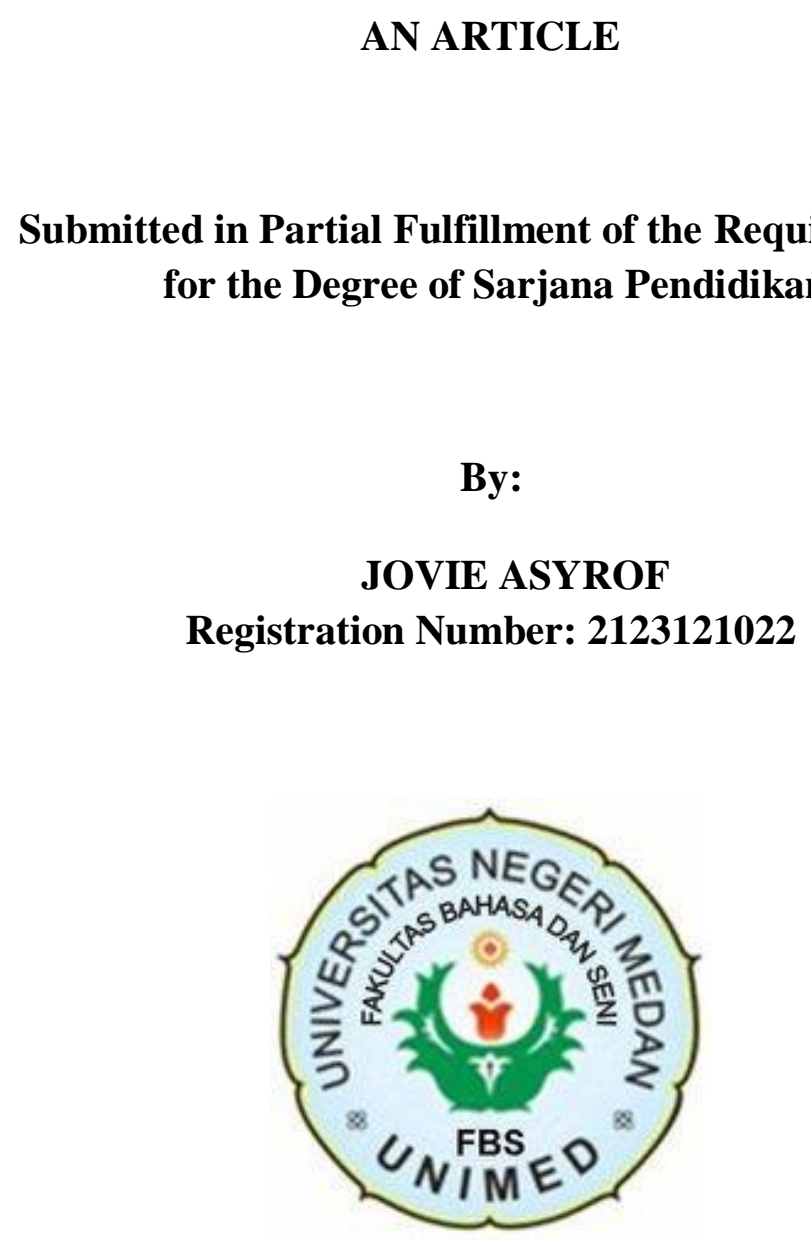

ENGLISH AND LITERATURE DEPARTMENT

FACULTY OF LANGUAGES AND ARTS STATE UNIVERSITY OF MEDAN 


\section{ARTIKEL}

Developing English Reading Materials for the Eleventh Grade Students of Maritime Department of SMK Pelayaran Samudera Indonesia

Disusun dan Diajukan oleh:

Jovie Asyrof

NIM. 2123121022

Telah diverifikasi dan dinyatakan memenuhi syarat

Untuk diunggah pada jurnal online

Medan, Oktober 2018

Menyetujui

Dosen Pembimbing Skripsi I

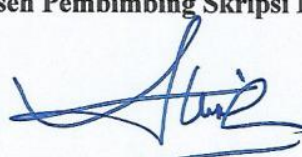

Prof. Dr. Hj. Sumarsih, M.Pd. NIP. 195810211983032002
Dosen Pembimbing Skripsi II

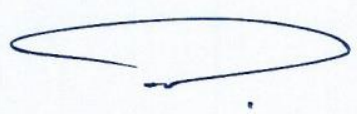

Dra. Masitowarni Siregar, M.Ed.

NIP. 196711021993032001

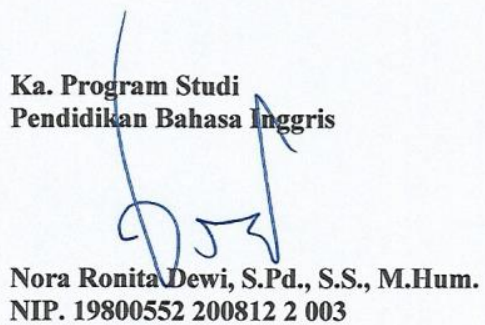




\title{
DEVELOPING ENGLISH READING MATERIALS FOR THE ELEVENTH GRADE STUDENTS OF MARITIME DEPARTMENT OF SMK PELAYARAN SAMUDERA INDONESIA
}

\author{
* Jovie Asyrof \\ ** Prof. Dr. Hj. Sumarsih, M.Pd. \\ ** Dra. Masitowarni Siregar, M.Ed. \\ Universitas Negeri Medan
}

\begin{abstract}
Jovie Asyrof. Registration Number: 2123121022. Developing English Reading Materials for the Eleventh Grade Students of Maritime Department of SMK Pelayaran Samudera Indonesia. A Thesis. English Educational Program, State University of Medan, 2018.

This research was aimed to develop suitable English reading materials for the eleventh grade students of Maritime Department of SMK Pelayaran Samudera Indonesia. Due to the result of this research was in the form of a product, this research was categorized as Research and Development (R \& D) which adapted Borg and Gall (2003) theory with some modifications. The subjects of this research were the eleventh grade students of Maritime Department of SMK Pelayaran Samudera Indonesia. In conducting this research, the procedures were gathering the data and information, conducting the need analysis, designing the first draft of materials, validating by the expert, revising the materials, and producing the final product. The instruments of collecting the data were the combination of two strategies; interview and questionnaires. The interview was analyzed as qualitative data and the questionnaires were analyzed as quantitative data. These data were the needs of students which covered target needs and learning needs. This research only focused on developing two genres of English reading materials based on KTSP that were taught in the second semester which were procedure and analytical exposition.
\end{abstract}

Keywords: English Reading Materials, English for Specific Purposes, Research \& Development $(R \& D)$, Maritime Department.

\footnotetext{
*Graduate Status

**Lecturer Status
} 


\section{A. Introduction}

Language is the most important thing in our life which we mostly use to communicate to other humans. Meyer $(2009$, p. 1) states, "language as one of many different systems of communication, a system that is unique to human beings and different from, for instance, the systems of communication that animals employ. Language exists in three modes: speech, writing, and signs (which are used by people who are deaf). Although all languages (with the exception of sign languages) exist in spoken form, only some have written forms."

There are thousands of languages and every country has its own official language. Some examples are China has Mandarin, United States has English and Indonesia has Indonesian for their official language. Difficulties will be appeared when these people try to communicate with each other, for instance: they will not be able to understand what others are saying when they try to communicate. To solve this problem, they need to speak the same language. Thus, this is where English comes in handy because it is the most commonly spoken language in the world.

In Indonesia, English language has important roles in some life aspects, for instance: popular movies, music and the contents in the internet are mostly in English; even most of the well paid job are also required English fluency. For that reasons, English has been made as one of the important subject in Indonesian high schools.

There are several high schools in Indonesia and one of them is vocational high school. In vocational schools, students learn English based on their need which is why they applied ESP method in the teaching processes. According to Hutchinson and Waters (1991, p. 19), "ESP is an approach to language teaching in which is all decisions of contents and method are based on the learner's reason for learning." Basically, what makes vocational school different from others; it is designed to have more specific practical knowledge on their field of work, which the students will use after they graduated. 
Even though English has become a subject in school and a necessity to get a better job, the majority of students still find it difficult to learn English. A long text which has complex grammar and no relation to their program are some of the reasons why students still find it difficult to learn English.

Based on the researcher's observation on SMK Pelayaran Samudera Indonesia, which has maritime as their major and still use KTSP as their curriculum, it was found that the learning materials were not specified for any specific program. It can be seen in the textbook government distributed to the students. They used "English for SMK" published by Yudhistira which based on KTSP. There were no reading materials in this book which related to maritime program.

One of the data as follows:

\section{Install the software}

1. Before you begin close all software applications that are open on your computer (including anti-virus software).

2. Place the Kodak Easyshare software CD into the CD-ROM drive.

3. Load the software:

Windows OS-based computer - if the install windows doesn't appear, choose Run from the start menu and type d:Isetup.exe where $d$ is the drive letter that contains the CD.

Mac OS 8.6 or 9.x - on the install window, click Continue.

Mac OS X - double-click the CD icon on the desktop, then click the Install icon.

4. Follow the on-screen instructions to install the software.

Windows OS-based computers - select Complete to automatically install the most commonly used applications. Select Custom to choose the applications you wish to install.

Mac OS 8.6 or 9. $x$ - select Easy to automatically install the most commonly used applications.

Mac OS X - Follow the on-screen instructions.

5. If prompted, restart the computer. If you turned off anti-virus software, turn it back on. See the anti-virus software manual for details.

The other reason why students are not interested in reading the materials, simply because they think it will not affect their future career. The students of maritime program are expected to be sailors who can understand both their native and English language because they will be needed to sail overseas in the 
future. That is why the students of maritime department need to learn with the materials related to their program.

Thus from the background above, it is suggested that the reading materials should be develop based on students' needs, vocational purpose as an application of ESP. By being provided reading materials based on the program they focus on, it would be easier for the students to understand the text.

\section{B. Theoretical Framework}

Reading is something that students mostly do every day in school, according to Serravallo (2010, p. 43) reading is "thinking and understanding and getting at the meaning behind a text. As children are read to during read-aloud, they are asked to think about characters, make predictions about what will come next, question and wonder what's happening, and consider what lesson they can learn from the book."

Armbruster (2011, p. 41) states, "comprehension is the reason for reading. If readers can read the words but do not understand what they are reading, they are not really reading."

From those definitions, it can be concluded that reading is a process of getting some information from a text which is also followed by comprehension skill.

English in vocational high school differs from English in the high school; unlike English in the high school which taught same lessons in every class, vocational high school has various of programs which demands specific English lesson which suitable for each programs, the goal of teaching English in vocational high school is aimed to improve student's intelligence, knowledge, personality, morals, and skills, to live autonomously and to follow higher education based on their vocational programs.

Based on Hutchinson's and waters' theories, English for Specific Purposes (ESP) is a way of teaching/ learning English for specialised subjects with some specific vocational and educational purpose in mind. Hutchinson and Waters (1987) also state that ESP is an approach which is based on the learners' needs. In line with that Basturkmen (2010, p.8) states, "in ESP the learner is seen as a language learner engaged either in academic, professional or occupational pursuits and who uses English as a means to carry out those pursuits". Therefore, ESP approach is used in this study to narrow the context of language teaching based on the target situation of the students. By using ESP approach, the English learning materials will be specified by, in this case, Maritime Program. 


\section{Research Methodology}

The researcher used Research and Development (R\&D) methodology and developed the materials through some stages; 1) Gathering data and information, 2) Analyzing data and students' need, 3) Designing the preliminary materials, 4) Validating by experts, 5) Revising, 6) Final product. The main goal of the researcher was to developed English reading materials for the eleventh grade students of maritime department at SMK Pelayaran Samudera Indonesia.

The data were analyzed in form of qualitative and quantitative. The qualitative data were collected from the result of interview section with the teacher. Then, the quantitative data were collected from the tabulation of the result of students' questionnaires and the checklist from expert validation. In addition, the subject of this research was the eleventh grade students' of SMK Pelayaran Samudera Indonesia in maritime department.

\section{Findings and Discussion}

The researcher distributed questionnaires with 20 questions in it. The questionnaires contained of target needs (students' background, goal, necessities, lack and want), and learning needs (input, procedure, setting). The researcher identified that the existing reading materials were not relevant to the students of maritime department. In other words, it was hard to the students to understand English because the materials were not related to their major. Thus, the results of the needs analysis were used by the researcher as guidance in developing English reading materials for the eleventh grade students of maritime department.

In this study, the researcher developed two genre text of reading materials related to maritime which are analytical exposition and procedure text which also ased on KTSP. The texts mostly talk about standard operational procedure and terms in maritime which related to students of maritime departmemt. In the development, some original ideas of the researcher and the expert were included. The researcher designed the layout of the text, added some authentic pictures and add some questions for the reading materials. 


\section{E. Conclusion and Suggestion}

\section{The Conclusion}

Based on the English curriculum of SMK, the target needs, and also the learning needs, the appropriate English learning materials for eleventh grade students of maritime department can be concluded as follows:

The English reading materials are based on the core competence and basic competences of KTSP for the eleventh grade students. Considering the basic competences and the needs analysis results, the appropriate topics of the English reading materials are about standard operation procedure and terms in maritime which related to maritime workplace. In addition, the learning input for reading activity are in the forms of procedure and analytical expositions texts which contains several technical terms for maritime. The length of the texts for reading activity are about 100-150 words. In addition, the reading materials provide input in terms of vocabulary and explanation about texts' structures to improve the students' comprehension skills. Meanwhile, the learning activities are reading the texts provided in the book, finding the meaning of words, answering true/false statements, and answering comprehension questions. Related to the setting, working in pair or in small group are preferable and good to enhance interactions among the students.

\section{The Suggestions}

The researcher suggests the teacher should do the need analysis in the beginning of the semester, in order to find the suitable materials which will ease the students in learning English. Also, the materials should be continuously developed to match the current needs of the students. 


\section{References}

Arias, I.J. (2007). Selecting Reading Materials Wisely. Journal of National University of Costa Rica, XL 131-151.

Armbruster, B.B. (2011). Put Reading First: The Research Building Blocks for Teaching Children to Read. Washington, DC: Partnership for Reading.

Basturkmen, H., (2010). Developing Courses in English for Specific Purposes. United Kingdom: Palgrave Macmillan

Gall, M.D., Gall, J.P., and Borg, W.R. (2003). Educational Research: An Introduction. Cambridge: Cambridge University Press.

Hutchinson, T., and Waters, A., (1991). English for Specific Purposes: A LearningCentered Approach. New York: Cambridge University Press.

Serravallo, J. (2010). Teaching Reading in Small Groups. Portsmouth, NH: Heinemann. 